\title{
Raffaello Caverni and his History of the Experimental Method in Italy
}

Raffaello Caverni is a controversial figure among the scholars of Galileo's work. Almost entirely ignored for half a century, his research has been more attentively considered only after his major work (Caverni 1891-1900) was reprinted in 1970.1

Caverni was born in Montelupo, not far from Florence, on 12 March 1837, into a modest family of brick manufacturers and carters. ${ }^{2}$ At the age of thirteen he began preparation for the Catholic priesthood in Florence, where he attended the secondary schools. He was ordained in June 1860 . During his vocational studies, Caverni showed particular interest in the natural sciences and deepened his scientific knowledge by attending classes in astronomy, mathematics, mechanics, and hydraulics at the Istituto Ximeniano in Florence. Since the autumn of 1859 to the end of 1870 he taught philosophy and mathematics at the seminary for priests in Firenzuola, a small village in the high Appennines. During this long period of retired life Caverni considerably, even if disorderly, extended his reading in the humanities as well as in the sciences. Naturalist observation in the field was also one of his favorite occupations. A number of notebooks and journals with book extracts, philosophical and religious reflections, literary attempts, and intimate thoughts still testify to Caverni's autodidactical work. ${ }^{3}$

At the end of December 1870 Caverni finally took over the little parish of Quarate in Bagno a Ripoli, in the outskirts of Florence, where he lived until his death on 30 January 1900 . The new appointment allowed him to pursue his scientific interests along with his pastoral duties for the following 29 years. In 1872 Caverni started to publish in periodicals for the family loose articles on curious mathematical problems, explanations of physical phenomena of everyday life, and also historical notes on scientific discoveries and inventions of instruments (Martini 1901, 296; Giovannozzi 1910, 265). Some of those unsystematic articles were later collected in a volume (Caverni 1882).

1 The first Italian reprint was published by Forni, Bologna, in 1970 . We refer to the second reprint, Caverni 1972. All references are concentrated in a bibliographic section at the end of the Appendix.

2 The biographical data are drawn from Procacci 1900, Martini 1901, Giovannozzi 1910 (also reproduced in Betti and Pagnini 1991, 17-34), Tabarroni 1972, Cappelletti and Di Trocchio 1979, Maffioli 1985, Betti and Pagnini 1991. For Caverni’s bibliography, see Mieli 1919-20, Cappelletti and Di Trocchio 1979, Betti and Pagnini 1991.

3 The papers are preserved by the Caverni family in Prato, Italy (Betti and Pagnini 1991, 175). 
The same lack of any apparent system characterizes Caverni's first book (Caverni 1874): a collection of essays on the most disparate subjects of mechanics, optics, astronomy, meteorology, and so on, that had been dealt with by Galileo, Borelli, Torricelli, and other seventeenth-century Italian savants. Clearly, the conceptual aspects of the "Galilean problems" rather than their historic authenticity were the focus of Caverni's treatment. As he explained in the foreword, ${ }^{4}$ his intention was not to faithfully reproduce old texts or reconstruct historical development, but rather to make understandable for a broader public of young readers what seemed to him of particular scientific interest. Thus, he had no problem with rewriting passages without marking his own changes (Betti and Pagnini 1991, 105).

The book attracted the attention of another beginner in the history of science, the young university professor Antonio Favaro, who wrote to Caverni praising his work and asking for quotations about the causes of earthquakes in the works of Galileo and his followers. ${ }^{5}$ This was not to be the last time that Favaro asked for Caverni's help in matters concerning Galileo.

In the years 1875-76 Caverni published a series of articles "on the philosophy of natural sciences," later also collected in a book (Caverni 1877a), dealing with problems posed to the traditional conceptions in ethics, theology, and metaphysics by the rapid growth of scientific knowledge. Essentially, he held a conciliatory position based on the orthodox dualistic view of the world recognizing, on the one side, the cognitive contribution of sciences in their own specific fields, the material world, while maintaining, on the other side, that sciences can say nothing about the spiritual world. The new and subversive idea was that even Darwin's theory of evolution should not be seen as contradicting religious beliefs, being only a hypothesis on the origin of animal species and their morphologic changes, and therefore not denying divine creation in principle. Of course, according to Caverni the biblical account was not to be taken literally (Giovannozzi 1910, 267-68); on the contrary, Galileo's hermeneutics was declared to be an "example to be imitated by future exegetes" (quoted in Maffioli 1985, 27). This show of intellectual boldness was not appreciated by the Catholic Church and the book was listed on the Index in 1878 (Giovannozzi 1910, 268; Tabarroni 1972, xi-xii), whereas it received warm appreciation by Favaro (Maffioli 1985, 56).

Caverni's intention, however, had not been to claim unquestioned validity of the Darwinian theory but to appeal to his fellow churchmen to carry on the dispute on a pertinent ground with better scientific arguments. For his part, as he made clear in a successive book (Caverni 1881), he was to a certain degree sceptical as to the reliability of paleontology in general and the theories on the origin and prehistory of man in particular, which were, in his opinion, extremely conjectural, with weak

\footnotetext{
4 The foreword is reprinted in Betti and Pagnini 1991, 104-07. This book also includes a selection of texts from Caverni's published works as well as manuscripts.

5 The relations between Favaro and Caverni are narrated and documented by Maffioli 1985, which we follow in our account; for Favaro's letter of 20 March 1875 see ibid., 56 . On Favaro and his editions of Galileo's works, see the biographical note in this Appendix.
} 
empirical foundation (Giovannozzi 1910, 268; Cappelletti and Di Trocchio 1979, 86).

As a true polymath with a paramount educational commitment, Caverni also wrote books on the language of Dante (Caverni 1877b) and on Italian literary style (Caverni 1879). Some years later followed popularizations of physics (Caverni 1884), of botanics (Caverni 1886b) and of mineralogical observations (Caverni 1888). In all the books of scientific popularization, he occasionally made historical digressions with the intent to arouse in the young readers esteem for the deeds of Italian savants and a desire to emulate them (Caverni 1972, 1:260-61). The wish to glorify the fatherland and to praise the Italian achievements in every field and especially in science can, indeed, be detected as a constant guiding motive in all the works of Caverni, whose "soul [was] woven with faith and nationality" (Giovannozzi 1910, 267).

Since the middle of the seventies, stimulated by Favaro who had become a personal friend and repeatedly asked for help in documentary research (Maffioli 1985, 31, 56-8), Caverni concentrated his studies on the history of Italian science. He got in the habit of going every Wednesday to the Biblioteca Nazionale Centrale of Florence, which had recently opened in premises of the Palazzo degli Uffizi adjacent to the Galleria (Tabarroni 1969, 564), and must have begun very soon to study the so-called Galilean Collection gathered by the Grand Dukes of Tuscany and now kept at the Library. This collection of more than 300 volumes of documents includes not only many manuscripts of Galileo, but also of his contemporaries as well as pupils and followers, documenting also the activity of the Accademia del Cimento and covering the period from the end of the sixteenth to the end of the seventeenth century and further. Caverni became one of the best and perhaps as yet unequaled experts of the entire collection, as shown by the material examined in his later publications.

Caverni's first scholarly publication in the history of science was on the invention and development of the thermometer (Caverni 1878). The subject was dealt with in the very traditional manner of priority disputes, aiming to state who had been the first to invent the instrument, who had improved it, and so on. His approach to the subject, however, was new compared with the works of contemporary Italian historians. The novelty was not so much that Caverni in his treatment kept to the sources and refused to follow established accounts on the principle of authority (Caverni 1878, 531), since these methodological rules were already accepted by the historians, even if, maybe, not always thoroughly respected. Caverni's new contribution consisted instead in the effort to reconstruct the process of invention by embedding it in a conceptual world. The story of the invention, with its personae and circumstances, was accompanied by a reconstruction of what was going on in "Galileo's mind"(Caverni 1878, 547). Addressing his attention to the philosophical frame in which the comprehension of heat phenomena could take place, Caverni showed that Galileo followed Platonian conceptions explaining heat as due to the major or minor quantity of heat corpuscles present in the body and argued that 
only on the basis of this theory was Galileo able to conceive of an instrument measuring the quantity of heat (ibid., 534-35, 543-44).

Of course, this kind of reconstruction was not possible without a certain degree of speculation with which not every historian would necessarily agree. Nevertheless some years later, in a chapter of his book on Galileo's Paduan period, Favaro explicitly followed Caverni in reconstructing Galileo's intellectual path (Favaro [1883] 1966, 197, 202, 204) adding only some new considerations on historical circumstances.

Notwithstanding Favaro's expressions of esteem, Caverni, in reviewing the book of his friend, made some critical remarks showing the differences of approach between the two historians (Caverni 1883; Maffioli 1985, 30-1). In Caverni's opinion, Favaro had given more room to the description of Galileo's "external life" than to the explanation of "the intimate life of the mind," meaning Galileo's intellectual work, of which Favaro had given only a resumptive exposition based on other authors instead of analyzing it. According to Caverni, as a consequence of this lack of penetrating study Favaro had accepted the account given by Vincenzio Viviani on the discovery of the isochronism of the oscillations of the pendulum on the basis of considerations concerning Viviani's trustworthiness, but he had not realized that some of Galileo's assertions on the phenomenon were experimentally untenable. "The fact is, "Caverni objected, "that the discovery was not occasioned by an observation, but was a corollary of geometrical mechanics." Viviani's account should be considered as a tale (Caverni 1883, 478-79).

Furthermore, Caverni reproached Favaro for having accepted Galileo's own claim of priority in the discovery that the trajectory of a projectile is a parabolic curve, without trying to explain why, then, Galileo never made use of or even mentioned the discovery until the end of his life (ibid., 479). Even in appreciating Favaro's work Caverni had a polemic undertone, since he pointed out that Favaro's studies on details of Galileo's life and world did not carry on the hagiographic tradition but contributed to "humanizing" Galileo (ibid., 477). We have to bear in mind that Favaro did not question the accepted stereotype of Galileo as the lonely and heroic founder of modern science but, on the contrary, he contributed to the fostering of the myth. ${ }^{6}$

In the review of Favaro's book there appears, although only indirectly and not thematized, another important change in the interpretation of Galileo's science that was to be developed in Caverni's later writings. The fact that Caverni explained the discovery of isochronism as a deduction from a more general theory and not as a result of occasional observation seems to indicate that he considered the conceptual system and not the experiment as the true determining factor in Galileo's scientific procedure.

Also in another review of a book written by Favaro (Favaro 1886a) Caverni

- On the Italian historiography on Galileo and Caverni's new approach, see Micheli 1988 and Landucci 1996. 
praised Favaro's erudition but in fact showed incomprehension for his work and at the same time made inadvertently clear how his own approach to the history of science was not thoroughly reflected (Caverni 1886a). Caverni did not appreciate the extensive exposition of the astrological works of Magini given by Favaro in order to reconstruct the cultural context of the cosmological controversies at Galileo's time. In Caverni's opinion, astrology was only superstition without connection to astronomy. Not aware of contradicting himself as to the role of the conceptual system in the process of scientific discovery, Caverni maintained that pure empirical evidence as given by the use of the telescope was enough to ruin astrology. According to him, Magini did not want to use it and stuck to astrology only because he was envious of Galileo (Caverni 1886a, 569). Clearly, Caverni did not yet have a coherent approach and jumped, so to say, from an explanation of a scientific tenet based on alleged personal factors to another explanation that took into account the conceptual reasons behind what the later story demonstrated to be an "error."

In spite of the already evident differences, Favaro involved Caverni in his project of a new edition of Galileo's works - which was to become the so-called Edizione Nazionale (Galilei 1890-1909) - since the early stages of its preparation in January 1883. He even proposed that they share the scientific responsibility of the edition and that Caverni take on the task of commenting on the scientific texts. In particular, Caverni was asked to work on the arrangement of the so-called $D e$ motu antiquiora, a set of Galileo's writings belonging to the Pisan period which were then published by Favaro in the first volume of the Edizione Nazionale, following in part the order suggested by Caverni (Maffioli 1985, 72-9). Yet, contrary to the original project, in 1887 it was finally decided that Galileo's texts should be accompanied only by historical notes and textual criticism, without the scientific explanations that Caverni had been envisaged for. As a consequence, Caverni was not appointed to the editorial board. This exclusion had an obvious negative effect on Caverni's relations with Favaro, but the collaboration between the two continued for a couple more years.

Meanwhile, since January 1886, Favaro was encouraging Caverni to take part in the contest for the "Tomasoni Prize," offered by the Venitian learned society "Reale Istituto Veneto di Scienze, Lettere ed Arti" for a work on the "history of the experimental method in Italy," especially "as applied to the physical sciences" from the beginning ot the fifteenth to the end of the seventeenth century (Favaro et al. [1889-90] 1972, 5). ${ }^{7}$ Favaro was not only a member of the institute, but also of the jury, and his later behavior suggests that he intended to favor Caverni. Three years later, in March 1889, Caverni sent to the institute a manuscript of more than 3,000 pages, making roughly 2,000 printed pages, treating almost exclusively Galileo and his disciples, with scarcely any attention given to the time before and

7 On Caverni's participation to the Tomasoni Contest and the coming into being of his Storia del metodo sperimentale we follow Tabarroni 1972 and Maffioli 1985. 
after them (Maffioli 1985,40). Nevertheless, the prize was given to Caverni but the tangled and occasionally farcical story of the adjudication and payment of the sum led to the definitive breakdown of personal relations between Favaro and Caverni. The reciprocal embitterment left a mark in their successive publications.

Caverni, for his part, taking notice of some of the critiques expressed by the judges (Favaro et al. [1889-90] 1972) -- actually by Favaro - as to the scope of the treatment, started to enlarge the original manuscript to an encyclopedic work, the Storia del metodo sperimentale in Italia (Caverni 1891-1900), that unfortunately remained unfinished because of the author's sudden death. In spite of its title, Caverni's Storia is not limited to the Italian scene but encompasses the history of science from ancient Greece to the end of the eighteenth century and further and deals, at least briefly, with all the major figures of the ancient world and of the European sciences, sweeping from Heron of Alexandria to Newton, from Archimedes to Volta.

Caverni intended to publish at least seven volumes but only six appeared, the last one posthumous and unfinished. ${ }^{8}$ The first volume begins with a 240 -page introductory essay expounding the author's methodological and philosophical guidelines interwoven with a compendium of the history of science with particular attention to Italy. Following to it are some chapters concerning the invention of instruments and technical devices. Caverni then deals in greater detail with the progress of optics, theory of heat, magnetism and electricity, metereology, and astronomy in the second volume, and with anatomy, physiology, zoology, botany, and mineralogy in the third. The fourth and fifth volumes are dedicated to mechanics and dynamics, focusing essentially on Galileo, so that some chapters can be read as a close commentary to Galileo's Discorsi e dimostrazioni matematiche intorno a due nuove scienze and the related manuscripts in the Florentine Library. Finally, the sixth volume deals with the progress of hydraulics up to Torricelli, a great part dedicated to the then unknown work of Viviani. According to Caverni's own plan, the seventh volume should also deal with hydraulics and even "other volumes" on the history of "moral sciences" were envisaged in case the author had enough time and energy (Caverni 1972, 1:260).

It has been observed that the work of Caverni represents the first systematic history of science in Italy conducted over a large documentary base and in accordance with a general, although rather simplistic and "naïve," theory concerning the acquisition and progress of knowledge (Micheli 1980,619; idem 1988, 184). Caverni's philosophical system certainly deserves deeper study. Here, however, we give only a succinct exposition of it.

8 The volumes were published in 1891 (vol. 1), 1892 (vol. 2), 1893 (vol. 3), 1895 (vol. 4), 1898 (vol. 5). The last one bears the date 1900 , but it was probably published after February 1905 or even after February 1910, since the old friend of Caverni, Father Giovannozzi, did not know of the existence of a sixth volume when he delivered his memorial speech on 6 February 1905 and the speech was published without correction exactly five years later (Giovannozzi 1910, 257, 272). The first notice of the existence of a sixth volume dates from summer 1916 (Favaro [1919-20a] 1992a, 141). A further chapter belonging to the sixth volume has been published in Giovannozzi 1928. 
Refusing straight-away but without argumentation "ontologist" systems and sensualism, Caverni takes as the starting point of his theory the conceptions of the common sense philosopher Thomas Reid, allegedly confirmed by pedagogists and novelists. According to Reid - in Caverni's interpretation - the first knowledge follows from the first human experience of maternal love, that is from an emotional experience between two persons. According to a "law of love and understanding" that is not specified further, the growth of knowledge is not due to spontaneous development but to the transmission of knowledge among people. From this Caverni infers "the necessity of traditions," in the sense that the transmission and growth of knowled ge can take place only within cultural traditions (Caverni 1972, 1:26-7).

Successively, Caverni elaborates a system whereby the development of mankind parallels the development of a human being from infancy to adulthood, a system in three phases reminiscent of Vico and Comte, although the phases are characterized in a different way. At each phase a new step in the growth of knowledge takes place. Following the theories of his contemporary pedagogist Raffaele Lambruschini regarding the psychological evolution of the child (Landucci 1996, 197), Caverni explains that at first the child is in "contemplation" of the world, it perceives the "superficial space," the "forms" of objects, and therefore "the first science learned by man is geometry." Subsequently, the child realizes that the world is something other than oneself, but "before it learns that the world rules itself with its own laws, it would like to be the lawgiver." Since the child's process of learning is the same as the process of acquisition of knowledge which a "civilized nation" goes through, it follows that "the law governing the intellectual development of an individual is the same one governing the intellectual development of a whole civilized nation." That means that in the history of every culture the sciences concerning "forms," such as geometry and mathematical astronomy, are the first to establish themselves, followed by a period in which general explanatory systems are conceived and imposed upon the world before the true laws of nature are discovered by the physical sciences. Among all nations, knowledge acquired in a particular phase is condensed in the work of a school founder and transmitted through it to posterity (Caverni 1972, 1:27-9).

According to this "historical law," the Platonian doctrines are seen as the analogue of the contemplative phase, during which mankind, and respectively the child, grasps the "forms," whereas Aristotelian philosophy corresponds to the "delirious" phase, during which the child imposes its own laws on the world. It is true, Caverni writes, that Platonian philosophy does not lead to experimental science, and moreover rejects it; but, on the other side, it contributes to the establishment of the theoretic preconditions for experimental science. Archimedes and Galileo are considered followers of Plato because they developed a geometrical science. Nor was Aristotle the initiator of experimental science; on the contrary, he provoked a regression because he attributed to reason the faculty of conceiving the general concepts from empirical particulars and devised artificial explanations for phenomena (ibid., 1:30-7). 
Also the later Peripatetics as well as the Italian rationalists of the sixteenth century conceived dogmatic and sterile systems that did not promote scientific progress (ibid., 1:60). Scientific progress since the later Middle Ages was not due to the followers of the two rival schools but to the non-academic practitioners of the arts, meaning painters as well as navigators, architects, and poets, epitomized by the figures of Leonardo, Columbus, Leon Battista Alberti, and Dante. According to Caverni, their merit was that they had directly observed, "interrogated" nature, in contrast to the bookish science of the Peripatetics of the Middle Ages. They represented the third phase of human development, after the "Platonian illusions" and the "Aristotelian deliriums," corresponding to the phase of individual development during which "man begins, through the candid use of senses, to acquire stable possession of the world" (ibid., 1:67-8).

Generally, however, Caverni tended to deny to the followers of Aristotle, or to those he considered to be speculative Aristotelians like, for example, Descartes and Bacon, any merit in the progress of science, while stressing the alleged Platonism of those who contributed to that progress, or at least the Platonic elements in their theories, so that in the end it appears evident that Caverni considered Platonism to be the only philosophical system that truly promotes science. In order to carry through his dichotomic schematization of the entire history of science, ${ }^{9}$ Caverni was forced to oversimplify and even misinterpret the thought of many authors. ${ }^{10}$

In this scheme, Galileo was listed among the Platonists because he considered geometry to be the instrument indispensable to discovering the laws of nature and because in some statements he allegedly denied validity to Aristotelian logic (ibid., 1:143). More generally, the Platonism of Galileo's "philosophia naturalis" seemed to consist for Caverni in the conception that the laws of nature as abstractions from empirical contingencies are "forms" with "geometrical regularity" (ibid., 1:241). Actually, Caverni did not support his interpretation with an analysis of Galileo's writings in connection with the culture of the time, so that the assertion remained unsatisfactorily corroborated and was questioned (Schiaparelli [1892] 1930, 20 n. 1). ${ }^{11}$

Even this short account makes clear that Caverni's theory concerning the development of science had at least two aspects that gave him a noted place in the history of scientific historiography. First of all, Caverni, far from being an erudite collector of sheer facts, was clearly aware of the debate of his time concerning the laws of scientific progress. In our opinion, he tried to syncretize the suggestions

9 "All the varieties of doctrinal systems appeared in the course of the centuries can be easily reduced to two types, the Aristotelian and the Platonian one" (Caverni 1972, 1:38-9).

10 In a review of the first volume the astronomer and historian of science Giovanni Schiaparelli blamed Caverni for having dealt with the history of philosophy following his feelings of likes and dislikes for the different thinkers (Schiaparelli [1892] 1930, 19). Micheli writes "Caverni's admiration for Plato is as excessive as his denigration of Aristotle" (Micheli 1988, 184).

11 On the feebleness of the treatment of Galileo's philosophy by Caverni, see Landucci 1996, 197-99. 
resulting from the then recent application of theories concerning biological evolution to the development of thought, as exemplified by his so to speak "recapitulation theory" of the growth of knowledge into a system based on the idealistic philosophy prevailing in the Italian Catholic tradition. ${ }^{12}$ Furthermore, Caverni approached the history of science from a challenging psychological perspective that, unfortunately, went unnoticed at the time. Without pretending to establish any kind of genealogical relation, we wish only to remark on the analogy between Caverni's and Piaget's approach to cognitive development.

However, as shown by the way he contrasted Platonism with Aristotelism, certain tenets and aspects of Caverni's system were very idiosyncratic, being more the expression of a passionate personality with strong preferences for some philosophical traditions, than the result of systematic reflection. Caverni also did not always stick to his theory of cognitive development, in particular concerning the problematic relation between experience and conceptual understanding, and often contradicted himself.

Of the entire philosophical scheme only the guiding concept of tradition found a fruitful application in Caverni's historiography of science. Caverni left undefined what he meant by the term "tradition," as well as how, in his opinion, tradition operates in history; but we can broadly understand the alleged necessity of tradition as the assertion that there is no solution of continuity or revolution in the transmission and growth of scientific knowledge. In Caverni's words, from the necessity of tradition it follows that "it is a philosophical error to admit the existence of truly creative geniuses"(Caverni 1972, 1:26-7). ${ }^{13}$ Accordingly, Caverni tried to show all along his work that new ideas and discoveries were the result of resumption and development of old ones. Caverni did not live long enough to take part in the disputes about continuity and revolution in the history of science but he was recognized as a kind of predecessor by Duhem who, some years later, explicitly agreed with Caverni's historiographic program although he rejected some of his specific reconstructions (Duhem 1909).

Actually, the results of Caverni's program are of a very different value. In some cases his search led simply to the redefinition of priority claims concerning invention of instruments or discoveries. In other cases Caverni detected in the words or concepts of older authors the precursors of later developments without consideration of their meanings in the original context. By emphasizing continuity on the basis of analogic linkages rather than of scientific meanings he tended to overlook the differences and thus misinterpreted the real progress. So, for example, he interpreted Newton's force of attraction merely as a more precise determination of Gilbert's magnetic forces (Caverni 1972, 2:356), or he saw in Newton's vis

12 Caverni's philosophy has been connected to that of the Italian catholic priest Antonio Rosmini, who lived in the first half of the nineteenth century (Giovannozzi 1910, 265; Micheli 1988, 184).

13 Similar statements can be found, e.g., in Caverni 1972, 4: 31, 69, 100, 328. 
inertiae only a new name for an older concept already used by Giovanni Battista Benedetti and Galileo (ibid., 4:302-03).

However, an important merit of Caverni was the light he shed on the scientific situation before Galileo, so that he could not be seen any more as an isolated genius, but as a one among others who continued an already existent trend of studies (ibid. 4:374). In particular, Caverni showed Galileo's dependency upon a tradition reaching from the pseudo-Aristotelian Quaestiones Mechanicae and Archimedes through Jordanus Nemorarius and Leonardo, till Niccolò Tartaglia, Benedetti, Guidobaldo del Monte and many other scholars who had not been studied before (ibid., 4:579-80; 5:169-70; 6:48-52, 75, 109-11; Segre 1991, 44-5).

More important, in his history of mechanics and hydraulics around Galileo, Caverni did not limit himself to superficial analogies but tried to reconstruct conceptual developments in connection with broader theoretical or experimental contexts. Following step by step the arguments of different authors, Caverni explained particular turns in the solution of problems or showed how new perspectives were opened up as a result of the intrinsic constraints of the conceptual and material instruments employed. Exemplary in this sense are the treatments of fall and resistance of bodies in the fourth volume, where alongside with the major authors a number of lesser known scientists are also considered in pages and pages of commented theorems and propositions.

Of particular interest is the reconstruction of the discovery of the parabolic shape of the trajectory of a projectile following the writings of Guidobaldo del Monte, Galileo, and others (Caverni 1972, 4:506-78). Caverni documented the fact that Guidobaldo as well as Galileo based their studies on this subject on a conceptual analogy established between the trajectory of a projectile and the catenary, that is the curve described by hanging chains, in so far as they both were considered to be the result of the "composition of natural and violent motion." As a consequence it was possible to suppose that the trajectory would make a curve like the catenary, possibly a parabola, and to perform experiments in order to prove it (ibid., 4:515-17). Furthermore, although he claimed that Galileo recognized the parabolic shape of the trajectory only after Cavalieri in 1632 derived it from the law of fall, Caverni suggested that the connection between the parabolic trajectory of a projectile and the law of fall could have easily been noticed already at an earlier stage and in this way he traced a link between the discovery of the law of fall and the studies on ballistics (ibid., 4:517-19). The suggested link was worthy of consideration and was resumed by Wohlwill (Wohlwill 1969, 1:145-46) but generally overlooked by the historiography for almost a century.

Caverni's study of conceptual developments was a great novelty in Italian history of science, which was then predominantly concerned with narration of deeds and summarization of books. Caverni instead maintained that the main subject of scientific historiography should be the "storia intima del pensiero," the development of thoughts in the scientist's mind. The difference of approach that had already come to light in the reviews of Favaro's books was now underscored in 
polemic references to "certain new editors" who transcribe manuscripts without understanding them (Caverni 1972, 5:262; see also 1:144). ${ }^{14}$ Caverni's focus on conceptual developments seems to originate from a specific comprehension of some intellectual features of scientific activity and from his intention to make this activity understandable in its own terms to a public of scientifically interested readers. For that reason he often insisted on the necessity of explanatory comments to the scientific texts (Caverni 1878, 535 n. 1; Caverni 1972, 1:83).

For a long time, the Italian historians of science were not able to appreciate and profit from Caverni's enormous pioneering work, partly because their approach was essentially erudite and not concerned with the genesis of concepts. Partly, also, because Caverni's re-evaluation of traditions and continuity in the transmission of knowledge was at odds with the predominant tendency to stress the radicality of change during the so-called scientific revolution in the seventeenth century, especially concerning the work of Galileo. ${ }^{15}$

Unfortunately, Caverni himself was partly responsible for the fact that his valuable insights were not appreciated and fell into oblivion after his death. One of the reasons was the anti-Galileian bias of his Storia. Introducing a disrupting factor in his scheme, Caverni argued that science from time to time becomes like an old kingdom without inner power and energy. In such phases according to Machiavelli only a tyrant that imposes his absolute will would be able to renew the state. Employing the metaphor of science as a kingdom, Caverni pictured Galileo as a repugnant personality who gave a decisive impulse to scientific progress albeit by imposing a tyrannical power upon the scientific community, appropriating the results of traditions while occulting them, and plagiarizing the discoveries of others (Caverni 1972, 1:127-28, 136-37, 140-43, passim; Schiaparelli [1892] 1930, 21). In order to belittle Galileo's contributions Caverni occasionally even concocted very implausible stories that would not stand historical analysis (e.g., Caverni 1972, 2:357-61; Favaro 1919-20b). ${ }^{16}$

This somewhat gothic image could not be accepted at a time when the predominant myth of Galileo was that he was alone in vindicating scientific rationality against obscurantism, a myth that was intermingled with the political struggle fought by the young Italian State against the Catholic Church. The reaction was correspondingly harsh, culminating in a kind of a "trial" against Caverni before the Italian historians of science nearly 20 years after the defendant's death, on the occasion of a congress of Italian scientists in April 1919 (Micheli 1987, 296; Del

14 On Caverni's conception of history of science as history of conceptual development, see, e.g., ibid. $4: 100 ; 5: 34,644-45$. A perspicuous evaluation of Caverni's approach is given by Maffioli 1985 , $27,49-52$.

is On the reception of Caverni's contributions to history of science, see Tabarroni 1969, 566-67: Tabarroni 1972, vii-viii; Baldini 1980, 384-85; Maffioli 1985, 27, 30; Micheli 1987, 296-98; Micheli $1988,184$.

16 Wohlwill called Caverni's account of Galileo's part in the discovery of parabolic trajectory a "fiction"(Wohlwill 1899, 607,612). Wohlwill's article is republished in this Appendix. The judgement was shared by Tannery 1900 . 
Lungo 1919). The critics, while recognizing the originality and richness of Caverni's research, blamed him as one who denigrated Galileo, but they did not discuss the general principles inspiring the Storia del metodo. In particular, Wohlwill and Del Lungo gave alternative accounts of discoveries of which Caverni had disputed Galilean paternity (Wohlwill 1899, Del Lungo 1921-22), while the implacable rival Favaro missed no opportunity to point out alleged factual errors and distorted interpretations in the work of the old friend (Favaro 1907a, 1919-20a and 1919-20b; Maffioli 1985, 30 n. 14). Today we can say that Caverni was right in bringing to light the scientific setting that preceded and surrounded Galileo, thus reducing his achievements to their more realistic dimensions. But in times of ideological conflict only a sober presentation would have had any chance of being fairly considered.

It was not only his exaggerations against Galileo that made Caverni unreliable as a historian for his contemporary colleagues. Caverni had not the habit of a meticulous scholar even by the standards of his time. Although he pretended to base his account exclusively on primary sources (Caverni 1972, 1:261-62; 5:645), and indeed mastered an impressive amount of new materials even making use of Galilean scratches that were ignored ever after, in fact Caverni showed an inexcusable disregard for the rules of accuracy and adherence to the sources, following which, during the nineteenth century, historiography was establishing itself as an accountable discipline. Caverni did not really acknowledge that textual criticism, which he openly despised (ibid., 4:341; Maffioli 1985, $35 \mathrm{n}$. 34), as well as correct bibliographical data and reconstruction of historical circumstances, are indispensable for any kind of historiography. Generally, he tended to base his account on the alleged intrinsic reasons of a development, but he did not care to deliver an adequate theory of conceptual production that would support his interpretation. On the other hand, he sometimes took into consideration for his reconstruction extrinsic facts like evolution of handwriting or differences in inks, but he did not follow clearly stated criteria in examining and interpreting the data and often fitted them arbitrarily into a preconceived story (Caverni 1972, 4:341-73). Caverni did not even shrink from forging texts, as Favaro documented in an article listing at least six passages of the Storia del metodo, sometimes many pages long, expressly quoted by Caverni as authored by Galileo or Viviani but in fact invented by Caverni himself (Favaro 1919-20a). ${ }^{17}$

In order to understand Caverni's behavior we should perhaps consider that his approach to scientific knowledge was that of an amateur who wished to share his enthusiasm with the reader. If, as we believe, his primary aim was to make everybody able to follow a thread of thought, it is not surprising that he saw nothing blameworthy in composing scattered tessera into a picture without gaps

\footnotetext{
17 An excerpt of this article is reprinted in this Appendix. In his apologetic introduction to the reprint of Storia del metodo sperimentale in Italia Tabarroni omits warning the modern reader about these fakes (Tabarroni 1972).
} 
instead of presenting them as partial and fragmentary as they are. The results are not without scientific interest for the modern reader, as shown by a dialog about the utiliy of catenary for the calculation of projectile trajectories (Caverni 1972, 5:143-53). ${ }^{18}$ One of the interlocutors describes a cardboard bearing perforated lines convincingly corresponding to a perforated paper sheet existing among the Galilean Manuscripts at the Biblioteca Nazionale of Florence. ${ }^{19}$ The explanations about the possible function of the carboard given in the pseudo-Galilean dialog by Caverni are undoubtedly pertinent, as well as the connections developed in the dialog between the propositions concerning the momentums of falling weights, the catenary and the parabolic trajectory of a projectile. In our opinion, Caverni had indeed understood the reasoning of Galileo. It is a pity that he did not expose his interpretation as such.

Max Planck Institute for the History of Science, Berlin (GC) Dipartimento di Filosofia e Teoria delle Scienze Umane, Facoltà di Magistero, Università di Cagliari (MC)

18 The dialog is reprinted in this Appendix.

19 Ms. Gal. 72, folio 41/42. The document has been published for the first time in Drake 1979, 238-39. It has been studied in Damerow et al. 1996 and in Renn et al. 1998, 9-11. 